\title{
MODEL PEMBELAJARAN PASSING BAWAH BOLA VOLI UNTUK USIA SEKOLAH DASAR
}

\author{
Rudi $^{1}$ dan Sandra Arhesa ${ }^{2}$ \\ Universitas Majalengka, Indonesia \\ email: alvarizi.rudi@gmail.com
}

\begin{abstract}
ABSTRAK. Tujuan dari penelitian adalah untuk menghasilkan model pembelajaran passing bawah bola voli untuk usia SD. Selain itu, penelitian dan pengembangan ini dilakukan untuk memperoleh informasi secara mendalam tentang pengembangan dan penerapan model passing bawah bola voli untuk usia sekolah dasar dan mengetahui efektivitas, efisiensi serta daya tarik anak terhadap model yang dibuat. Penelitian ini menggunakan metode penelitian pengembangan Research \& Development (R\&D) dari Borg and Gall. Subyek dalam penelitian dan pengembangan ini adalah siswa-siswi SD yang terdiri dari 35 anak. Instrumen yang digunakan dalam penelitian dan pengembangan ini adalah angket, kuisioner, serta instrumen test passing bola voli yang digunakan untuk mengumpulkan data passing bawah bola voli anak usia SD. Uji efektifitas model menggunakan tes passing bawah untuk mengetahui tingkat kemampuan passing bawah bola voli untuk usia SD sebelum pemberian treatmen berupa model passing bawah yang dikembangkan dan untuk mengetahui tingkat kemampuan passing bawah setelah perlakuan atau treatmen model passing bawah yang dikembangkan, dari tes awal yang dilakukan diperoleh tingkat passing bawah siswa sebesar 65,83 kemudian setelah diberikan perlakuan berupa model passing bawah diperoleh tingkat kemampuan passing bawah siswa sebesar 91,66 Maka model passing bawah bola voli ini efektif dalam meningkatkan pembelajaran passing bawah bola voli untuk usia sekolah menengah pertama. Berdasarkan hasil pengembangan dapat disimpulkan bahwa diperoleh bukti adanya peningkatan ini di tunjukan pada hasil pengujian data hasil pretes dan posttest adanya perbedaan yang signifikan antara sebelum dan sesudah adanya perlakuan model.
\end{abstract}

Kata Kunci: Pembelajaran; Passing Bawah

\section{Pendahuluan}

Bola voli merupakan salah satu cabang olahraga yang termasuk materi wajib dalam matapelajaran pendidikan jasmani yang harus diajarkan di sekolah- sekolah. Keterlibatan siswa dalam program pembelajaran bola voli diharapkan dapat membantu mengoptimalkan perkembangan dan pertumbuhan siswa, meningkatkan komponen kebugaran jasmani siswa, seperti: daya tahan kekuatan, power, kelentukan, kelincahan, keseimbangan dan koordinasi gerak. Selain mengembangkan aspek fisik pembelajaran bola voli juga diharapkan dapat mengembangkan aspek mental seperti motivasi belajar, percaya diri, keberanian dan disiplin, sikap toleransi dan kerjasama yang merupakan aspek sosial juga diharapkan mengalami perubahan ke arah yang lebih baik. Muhajir (2007). Permainan bola voli adalah suatu cabang olahraga berbentuk memvoli bola di udara bolak-balik di atas jaring/net dengan maksud dapat menjatuhkan bola di dalam petak lapangan lawan untuk mencari kemenangan. Dalam permainan bola voli dapat di pergunakan bagian tubuh mana saja asalkan perkenaanya harus 
sempurna (tidak ganda), permainan bola voli dapat dimainkan oleh dua regu yang masingmasing regu terdiri dari enam orang pemain.

Inovasi yang bisa dilakukan untuk meningkatkan hasil belajar dalam mata pelajaran pendidikan jasmani sangat banyak cara dan metodenya, baik inovasi dalam hal sarana prasarana belajar, metode dalam mengajar, pendekatan dalam proses pembelajaran, dan lain sebagainya. Dalam proses pembelajaran pendidikan jasmani diharapkan guru mampu memberikan ilmu dan pengetahuan secara menyeluruh. Pada proses pembelajaran pendidikan jasmani seorang guru tentunya harus memperhatikan karakteristik usia pada masing-masing jenjang pendidikan, karena desain pembelajaran pendidikan jasmani mengacu pada kemampuan keterampilan sesuai teori fase-fase perkembangan anak. Secara sederhana, pembelajaran motorik dapat diartikan sebagai proses belajar kehalian gerakan dan penghalusan kemampuan motorik, serta variabel yang mendukung atau menghambat kemahiran maupun kehalian motorik. Menurut Decaprio (2013). Aspek pembelajaran motorik dalam pendidikan merupakan “Aspek yang berhubungan dengan tindakan atau perilaku yang ditampilkan oleh para siswa setelah menerima materi tertentu dari guru".

Berdasarkan pendapat di atas dapat disimpulkan bahwa tujuan dari partisipasi siswa dalam pembelajaran bola voli adalah untuk meningkatkan keterampilan gerak dasar, meningkatkan komponen kebugaran jasmani, mengembangkan keterampilan motorik, memperkenalkan keterampilan passing bawah bola voli dan membantu meningkatkan kepercayadirian siswa. Tujuan yang ingin dicapai melalui program pembelajaran bola voli di sekolah berbeda dengan tujuan pada klub bola voli prestasi. Pembelajaran bola voli disekolah lebih menekankan pada pencapaian tiga aspek secara utuh yaitu aspek kognitif, afektif dan psikomotor.

Levin (2008) menyatakan "Every child is capable of being creative. However, when pupils are forced to suppress their creativity by participating in an activity they dislike or which does not motivate them, then their response can lead to inappropriate behavior". Pernyataan tersebut menjelaskan bahwa setiap anak memiliki kemampuan dalam mengembangkan kreativitas, tetapi ketika anak dipaksa untuk menekankan kreativitas mereka dengan berpasrtisipasi dalam suatu kegiatan yang tidak disukai atau yang tidak memotivasi mereka, maka kreativitas sulit untuk dimunculkan. Kelemahan dalam pendidikan jasmani sering terjadi pengembangan model yang monoton sering membuat siswa mengalami kejenuhan dalam mengikuti mata pelajaran pendidikan jasmani. Sehingga diharapkan dalam menggunakan model-model ini guru bisa menyelaraskan dengan kondisi dan situasi yang dihadapi oleh siswa. Pembuatan model pengembangan yang tepat di dalam materi passing 
bawah yang tentu saja gerakannya harus mendukung yang berhubungan dengan passing bawah (permulaan, perkenaan, dan gerakan lanjutan). Terkait dengan pernyataan-pernyataan yang telah dikemukakan di atas maka hal tersebut menunjukkan bahwa perlu dikembangkan model passing bawah bola voli, yang nantinya dapat dijadikan sebagai solusi untuk memudahkan siswa dalam belajar passing bawah secara lebih efektif.

Berdasarkan hasil observasi dan wawancara penulis dengan guru pendidikan jasmani ditemukan fakta-fakta sebagai berikut: Proses pembelajaran passing bawah bola voli di sekolah dasar berjalan lancar, akan tetapi tidak semua materi yang diamanatkan kurikulum dapat dilaksanakan, metode yang diajarkan dalam mengajar masih konvensional, tujuan pembelajaran belum tercapai dengan indikator kecukupan gerak siswa belum terpenuhi, dan keterampilan gerak siswa belum termasuk katagori baik, Sarana dan prasarana untuk pembelajaran bola voli masih sangat kurang, program pembelajaran bola voli yang diterapkan pada kegiatan intrakurikuler masih mengacu pada program pembelajaran bola voli prestasi. Untuk mengatasi permasalahan dalam pembelajaran passing bawah bola voli seperti yang telah dipaparkan di atas, maka penelitian dan pengembangan model pembelajaran passing bawah bola voli untuk siswa sekolah dasar penting untuk dilakukan.

\section{Metode Penelitian}

Pendekatan yang dipergunakan dalam penelitian ini adalah pendekatan kualitatif dan kuantitatif, yang merupakan pendekatan untuk menemukan jawaban dari masalah melalui rumusan masalah yang telah dirumuskan dalam Bab I yaitu pembelajaran passing bawah bola voli untuk usia SD. Penelitian dan pengembangan (Research and Development) menurut Borg \& Gall (1983) adalah suatu proses yang dipakai untuk mengembangkan dan memvalidasi produk pendidikan. Penelitian dan pengembangan (research and development) menurut Sugiyono (2010) adalah metode penelitian yang digunakan untuk menghasilkan produk tertentu, dan menguji keefektifan produk tersebut. Pengembangan menurut Setyosari (2005) yaitu, suatu proses yang dipakai untuk mengembangkan dan memvalidasi produk pendidikan, dapat berupa proses, produk dan rancangan.

Penelitian dan pengembangan dalam pembelajaran ini menggunakan pendekatan kualitatif dan kuantitatif serta menggunakan model pengembangan Research \& Development $(R \& D)$ dari Borg dan Gall yang terdiri dari sepuluh langkah atau dapat juga digambarkan dalam bentuk skema tahapan pengembangan seperti pada gambar dibawah ini: 


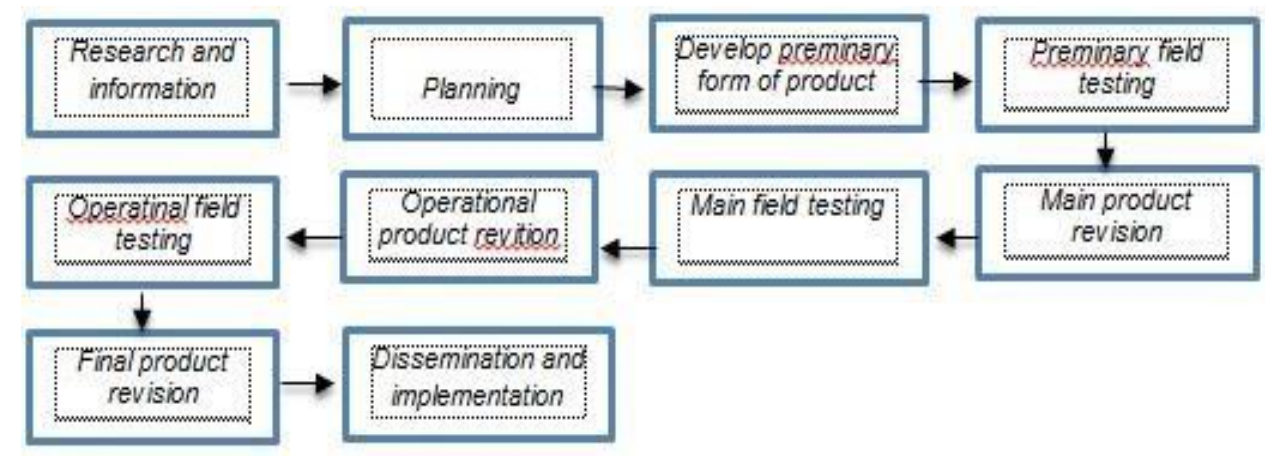

Gambar 1. Instructional Design $R \& D$

\section{Hasil dan Pembahasan (12 pt)}

Bahwa ada 27 dari 29 bentuk model pembelajaran yang telah dikembangkan, Berdasarkan uji ahli yang dilakukan tentang model pembelajaran passing bawah bola voli untuk usia SD dapat ditarik kesimpulan sebagai berikut: (1) Berdasarkan uji ahli yang dilakukan dapat disimpulkan bahwa variasi model 9 dan 27 merupakan model pembelajaran yang tidak layak diberikan pada siswa SD. (2) Untuk variasi model pembelajaran 29 dilihat memiliki tingkat kesulitan yang sedang sehingga dapat memudahkan siswa dalam melakukan gerakan, akan tetapi untuk dapat lebih meyakinkan lagi variasi ini akan dilihat efektifitas dan kelayakannya setelah ujicoba kelompok kecil. (3) Berdasarkan uji ahli yang dilakukan dari 29 variasi pembelajaran menyisakan 27 variasi pembelajaran yang akan di ujicobakan pada tahap selanjutnya. (4) Petunjuk pelaksanaan harus dibuat secara jelas supaya mudah untuk dipahami.

\section{Uji Efektivitas}

Menghitung uji efektifitas menggunakan (uji t) dengan analisis perbedaan dua rerata untuk sampel tak bebas seperti pendapat pada Kadir (2010) tentang sampel tak bebas adalah sampel yang keberadaannya saling mempengaruhi (berkorelasi). Dalam perhitungan menggunakan SPSS 16 dengan analisis paired sample $t$-test.

Paired Samples Statistics

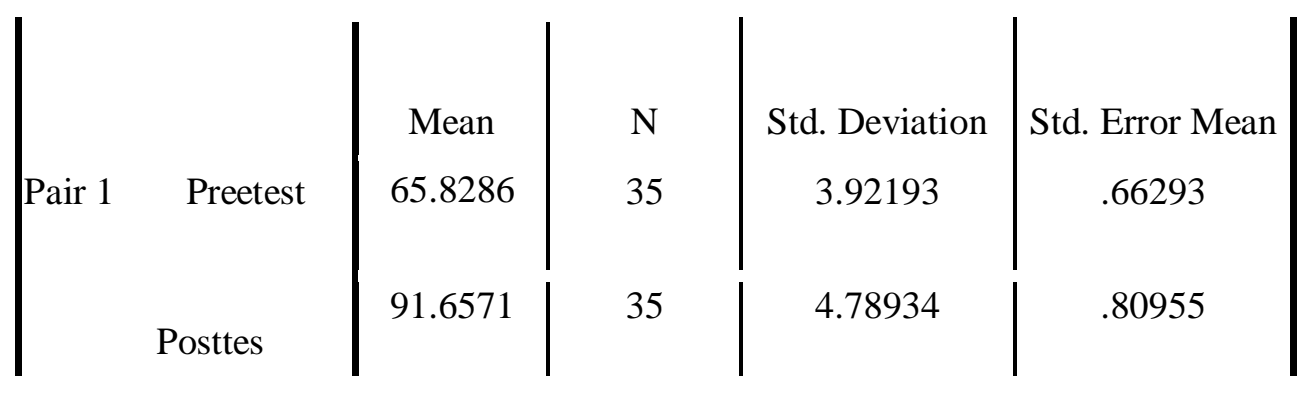


Berdasarkan hasil output dengan menggunakan SPSS 16 bahwa nilai rata- rata hasil pembelajaran passing bawah bola voli sebelum diberikan model pembelajaran adalah 65.83 dan setelah diberikan perlakuan dengan model pembelajaran 91.66 artinya bahwa nilai rata-rata passing bawah adanya peningkatan.

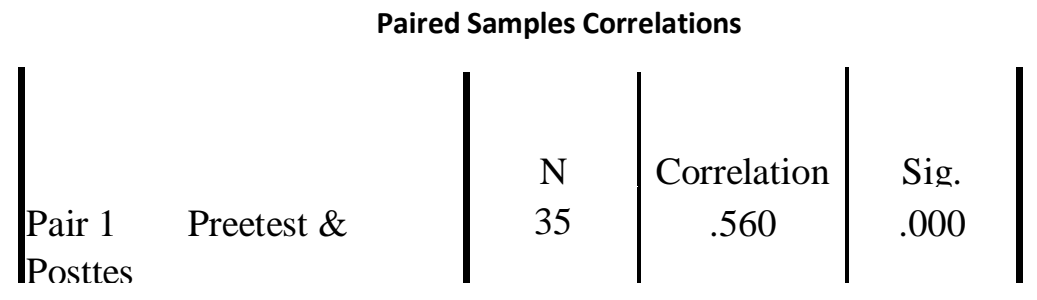

Berdasarkan hasil ouput tabel di atas bahwa koefisien korelasi kelincahan sebelum dan sesudah diberikan model pembelajaran kelincahan adalah 0.560 dengan p-value $0.00<0.05$ jadi kesimpulannya singnifikan.

\section{Paired Samples Test}

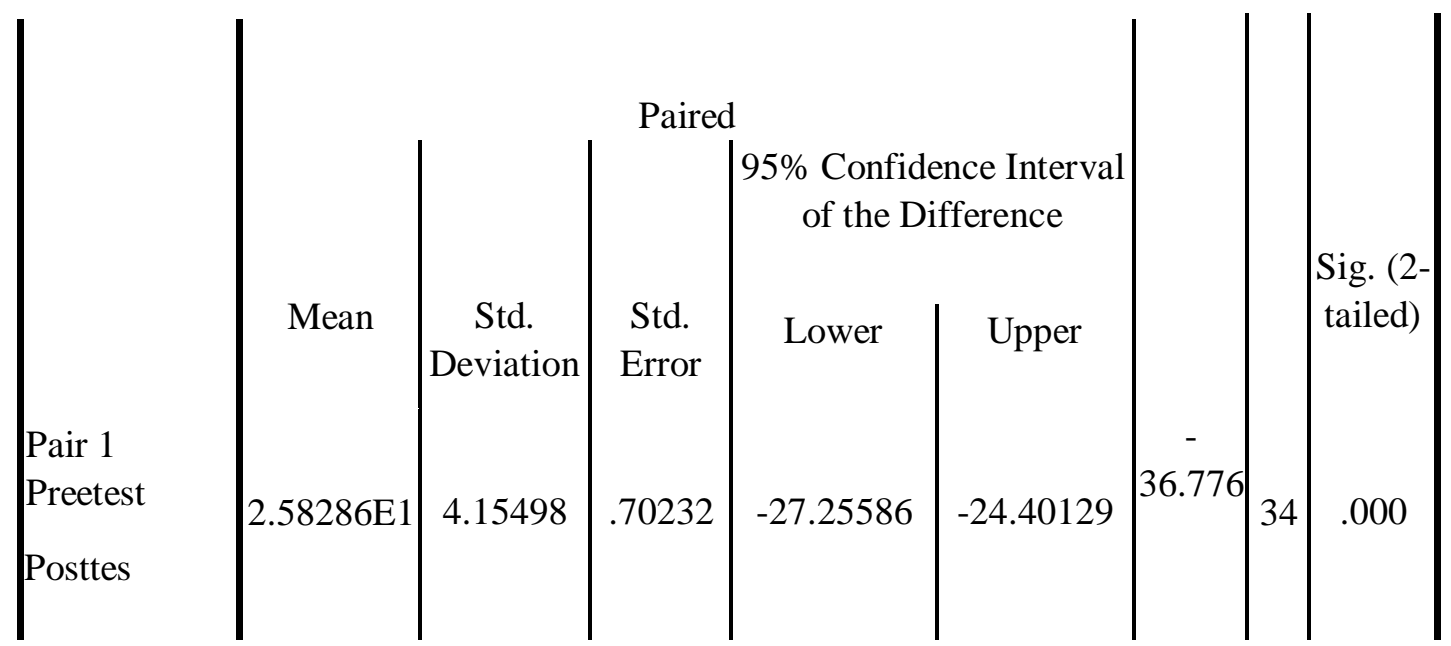

Dalam uji signifikansi perbedaan dengan SPSS 16 didapat hasil t-hitung $=36,78, \mathrm{df}=$ 34 dan p-value $=0.00<0.05$ yang berarti terdapat perbedaan yang signifikan pembelajaran passing bawah siswa sebelum dan sesudah adanya perlakuan model pembelajaran passing bawah bola voli.

Berdasarkan keterangan tersebut dapat dikatakan bahwa model pembelajaran passing bawah bola voli untuk usia sekolah dasar yang dikembangakan, efektif dapat meningkatkan pembelajaran passing bawah bola voli untuk usia SD.

Hasil ujicoba kelompok kecil dan ujicoba kelompok besar dapat disimpulkan bahwa Model passing bawah bola voli untuk usia SD dapat digunakan dalam proses pembelajaran passing bawah bola voli untuk usia SD serta layak dan efektif untuk meningkatkan passing bawah siswa. 


\section{Kesimpulan}

Berdasarkan data yang diperoleh, dari hasil uji coba lapangan dan pembahasan hasil penelitian dapat disimpulkan bahwa: Dengan model passing bawah anak usia SD dapat belajar materi passing bawah secara efektif dan efisien. Dengan materi passing bawah yang telah peneliti kembangkan, anak usia SD dapat memahami materi passing bawah dengan cepat dan benar.

\section{Daftar Pustaka}

Borg. W. R \& Gall. M. D. 1983. Educational Research An Introduction. New York: Longman. Decaprio, Richard. (2013). Aplikasi Teori Pembelajaran Motorik di Sekolah. Jogjakarta: Diva Press. Husdarta. (2011). Manajemen Pendidikan Jasmani. Bandung: Alfabeta. Kadir. Statistik Untuk Penelitian Ilmu-Ilmu Sosial, Jakarta: Resamata Sampurna.

Lavin Jim. (2008). Creative Approaches to Physical Education Helping Children to Achieve Their True Potensial. Canada: Routledge.

Muhajir. (2007). Pendidikan Jasmani Olahraga \& Kesehatan, Bandung: Ghalia Indonesia Printing. Setyosari, Punaji. 2013. Metode Penelitian Pendidikan dan Pengembangan Jakarta: Prenada Media Group.

Sugiyono. (2010). Metode Penelitian Kuantitatif, Kualitatif dan R \& D. Bandung: Alfabeta. 